\title{
The catalytic and regulatory properties of aspartate transcarbamoylase from Pyrococcus abyssi, a new deep-sea hyperthermophilic archaeobacterium
}

\author{
Cristina Purcarea,' Gaël Erauso, ${ }^{2}$ Daniel Prieur ${ }^{2}$ and Guy Hervé \\ Author for correspondence: Guy Hervé. Tel: +331422200 79. Fax: +33142221398. \\ e-mail: arpep1@citi2.fr
}

1 URA CNRS 1682, Université Pierre et Marie Curie, Laboratoire de Biochimie, 96 Bd Raspail, 75006 Paris, France

2 UPR CNRS 4601, Station Biologique, Laboratoire de Bactériologie Marine, 29680 Roscoff, France

\begin{abstract}
The catalytic and regulatory properties of aspartate transcarbamoylase from Pyrococcus abyssi were studied in the GE5 strain isolated from a deep-sea hydrothermal vent located in the North-Fiji Basin in the SW Pacific Ocean. The enzyme from this hyperthermophilic archaeobacterium shows homotropic cooperative interactions between catalytic sites for the utilization of its two substrates, carbamoylphosphate and aspartate. The activity of this enzyme is subject to allosteric regulation. It is feed-back inhibited by the end-product cytidine triphosphate independently of temperature. In contrast, its sensitivity to the feed-back inhibitor uridine triphosphate and to the activator adenosine triphosphate disappears at high temperature. The unusual response of this aspartate transcarbamoylase to carbamoylphosphate analogues suggests a particular mode of binding of this substrate to the catalytic site as compared to the homologous enzymes of other organisms. Aspartate transcarbamoylase of Pyrococcus abyssi exhibits a remarkable stability towards high temperature and pressure.
\end{abstract}

Keywords: Pyrococcus abyssi, archaeobacteria, hyperthermophily, aspartate transcarbamoylase

\section{INTRODUCTION}

Extreme conditions (temperature, pressure, $\mathrm{pH}$, solvent) are increasingly used to study structure-function relationships in biological macromolecules (Lowe et al., 1993). One aim of such studies is to uncover the molecular mechanisms through which living organisms can adapt to extreme environmental conditions. Hyperthermophilic micro-organisms have been particularly closely studied (Brock, 1978; Stetter et al., 1990; Lowe et al., 1993; Adams, 1993). The comparison of primary structures from homologous enzymes of hyperthermophilic and mesophilic bacteria suggests that resistance to high temperature can be the result of very discrete structural changes (Brock, 1978; Argos et al., 1979; Yutani et al., 1982; Imanaka et al., 1986; Ganter \& Plückthun, 1990; Ishikawa et al., 1993) and that the increase in thermostability results from diverse mechanisms. The first studies were made on thermophilic and hyperthermophilic bac-

Abbreviations: ATCase, aspartate transcarbamoylase; CPSase, carbamoylphosphate synthetase; CP, carbamoylphosphate; PALA, N(phosphonacetyl)-L-aspartate. teria (growth temperature above $60^{\circ} \mathrm{C}$ ) isolated from hot springs located in volcanic areas.

More recently (Corliss \& Ballard, 1977), the discovery of deep-sea biotopes located close to hydrothermal vents brought attention to organisms which are living under high hydrostatic pressure. Among these organisms there are hyperthermophilic bacteria which are adapted to both high pressure and temperature. Many of the bacteria living in these extreme environments are Archaea (previously known as Archaeobacteria) (Woese et al., 1990). In order to understand the mechanisms of their adaptation to these unusual conditions it is necessary to study the structure and the properties of the essential enzymes of these organisms on which their metabolism relies.

One of these micro-organisms, Pyrococcus abyssi (strain GE5), was recently isolated from a deep-sea hydrothermal chimney located $2000 \mathrm{~m}$ deep in the North-Fiji Basin (SW Pacific) (Auzende et al., 1989; Erauso et al., 1992). This strain was characterized as an obligate anaerobe hyperthermophilic archaeobacterium belonging to the sulphurmetabolizing group. At atmospheric pressure its optimum temperature growth is $96^{\circ} \mathrm{C}$, with a doubling time of 
33 min. P. abyssi is barotolerant to barophilic; its growth is stimulated under high hydrostatic pressure, showing adaptation to these conditions (Erauso et al., 1993).

A problem related to cell growth at high temperature is the instability of some intermediary metabolites. This is the case of carbamoylphosphate (CP) which is necessary for the biosynthesis of pyrimidine nucleotides and arginine. In the pyrimidine nucleotides pathway carbamoylphosphate is a substrate of aspartate transcarbamoylase (ATCase), the first enzyme unique to this pathway. This enzyme plays an important role in metabolic regulation and ATCase from Escherichia coli is extensively used as a model system to study the molecular mechanisms of cooperativity, allostery and intramolecular signal transmission (Allewell, 1989; Hervé, 1989; Kantrowitz \& Lipscomb, 1990; Lipscomb, 1992).

Aspartate transcarbamoylase and carbamoylphosphate synthetase have been studied in various organisms, from bacteria to mammals, and these enzymes allow interesting investigations concerning molecular evolution of protein structure and allosteric regulation (Davidson et al., 1993; Hervé et al., 1993). In view of these interests, the catalytic and regulatory properties of ATCase were studied in the GE5 strain of $P$. abyssi. The partial purification of this enzyme has led to uncontrolled alterations of its structure and regulatory properties. Here we describe a study of its properties in dialysed cell-free extracts. The results show that ATCase from $P$. abyssi exhibits both homotropic cooperative interactions between catalytic sites and allosteric regulation. Its activity is highly resistant to both high temperature and pressure.

\section{METHODS}

Chemicals. Carbamoylphosphate (lithium salt), L-aspartate, succinate (sodium salt), phosphonacetate (sodium salt), pyrophosphate, diethanolamine (DEA), $N$-ethylmorpholine (NEM), 2-(N-morpholino)-ethane sulphonic acid (MES), adenosine triphosphate (sodium salt), cytidine triphosphate (sodium salt) and guanosine $5^{\prime}$-triphosphate, type I (sodium salt) were purchased from Sigma; Tris was from Prolabo; Titriplex III (EDTA) from Merck; uridine triphosphate (sodium salt) from Pharmacia ; 2-mercaptoethanol and antipyrine (1,5-dimethyl-2phenyl-3-pyrazolone) from Kodak; diacetyl monoxime (2,3butanedione monoxime) from Aldrich; and $\left[\mathrm{U}^{14}{ }^{14} \mathrm{C}\right]$ aspartate $\left(300 \mathrm{mCi} \mathrm{mmol}^{-1} ; 11 \cdot 1 \mathrm{GBq} \mathrm{mmol}^{-1}\right.$ ) from CEA-Saclay. $N$ (Phosphonacetyl)-L-aspartate (PALA) was a generous gift from Drs V. Narayanan and L. Kedda of the Drug Synthesis and Chemistry Branch, Division of Cancer Treatment, NIH, Silver Spring, MD, USA.

Cell culture. P. abyssi strain GE5 (CNCM I-1302) was grown under anaerobic conditions, at $95^{\circ} \mathrm{C}$, in an artificial sea water medium containing elemental sulfur $\left(\mathrm{S}^{0}\right)$ and supplemented with bactopeptone and yeast extract (YPS) (Erauso et al., 1993). The wet weight yield obtained was about $2 \mathrm{~g} \mathrm{l}^{-1}$.

Preparation of dialysed cell-free extracts. Cells frozen at $-80^{\circ} \mathrm{C}$ were suspended into TBE buffer (containing Tris $/ \mathrm{HCl}$, $\mathrm{pH} 8,50 \mathrm{mM}$; 2-mercaptoethanol, $1 \mathrm{mM}$; EDTA, $0 \cdot 1 \mathrm{mM}$ ) and disrupted by sonication six times for $30 \mathrm{~s}$ using a Biosonik III sonicator. The extracts obtained were centrifuged at $7000 \mathrm{~g}$ and the supernatant was dialysed against the same buffer overnight, at $4{ }^{\circ} \mathrm{C}$, to eliminate small metabolites, especially nucleotide derivatives, which might interfere with the ATCase activity.

Enzyme assay. Aspartate transcarbamoylase activity was measured by the radioactive test using $\left[{ }^{14} \mathrm{C}\right]$ aspartate (Perbal \& Hervé, 1972). The ATCase specific activity of dialysed extracts is expressed in units ( $\mathrm{mg}$ protein) ${ }^{-1}$. One unit (U) is defined as $\mu$ mol carbamoylaspartate formed $\mathrm{h}^{-1}$. The standard conditions used were $20 \mathrm{mM}$ aspartate, $5 \mathrm{mM}$ carbamoylphosphate and $50 \mathrm{mM}$ Tris $/ \mathrm{HCl}$, at $\mathrm{pH} 8$ and incubation at $37^{\circ} \mathrm{C}$, unless otherwise indicated. When the incubations were performed at $90^{\circ} \mathrm{C}$, the carbamoylphosphate concentration was $40 \mathrm{mM}$.

Influence of the allosteric effectors. Nucleoside triphosphate (ATP, CTP, UTP, GTP) solutions were buffered at $\mathrm{pH}$ 8. Their influence on the rate of the ATCase reaction was measured as previously described (Kerbiriou \& Hervé, 1972) in the presence of $3 \mathrm{mM}$ aspartate (Thiry \& Hervé, 1978) and the percentage of stimulation or inhibition is expressed as:

$\%$ activation $=\frac{V_{\mathrm{a}}-V_{0}}{V_{0}} \times 100$

$\%$ inhibition $=\frac{V_{0}-V_{1}}{V_{0}} \times 100$

where $V_{0}$ is the reaction rate in the absence of nucleotides while $V_{a}$ and $V_{i}$ are the reaction rates in the presence of activator and inhibitor, respectively.

pH-dependence assay. The buffer system used to determine the $\mathrm{pH}$-dependence of the activity is composed of $0.051 \mathrm{M} \mathrm{DEA}$, $0.051 \mathrm{M}$ NEM and $0.1 \mathrm{M}$ MES adjusted at different $\mathrm{pH}$ between 6 and 10 (Leger \& Hervé, 1988), using a Knick 655 pH meter and an Ingold microelectrode. Adjustments were made at $37^{\circ} \mathrm{C}$.

Pressure assay. Hydrostatic pressure tests were performed in a high-pressure reactor that allows injection, mixing and sampling at constant pressure (Hui Bon Hoa et al., 1990). When the apparatus was used to follow the rate of reaction as a function of pressure, $300 \mu \mathrm{l}$ samples were collected in $0.7 \mathrm{ml} 0.2 \mathrm{M}$ acetic acid to stop the enzymic reaction. The amount of carbamoylaspartate formed was then determined by the colorimetric test (Prescott \& Jones, 1969).

Protein assay. Protein was determined by the Lowry method, using bovine serum albumin as standard.

Data processing. All the kinetic data were treated with the KaleidaGraph program on a Macintosh computer. The substrate saturation curves were fit either to the Hill equation or to the Michaelis-Menten curves.

\section{RESULTS}

\section{ATCase activity of $\boldsymbol{P}$. abyssi cell-free extracts}

An ATCase activity can be measured in the dialysed cellfree extract of the GE5 strain of $P$. abyssi. In consideration of the thermal lability of the substrate carbamoylphosphate (CP) and of some other metabolites used in this study, this activity was characterized at $37^{\circ} \mathrm{C}$. Furthermore, when possible, the most important properties of the enzyme were subsequently investigated at $90^{\circ} \mathrm{C}$. The ATCase specific activity of these extracts varied by a factor of five from one culture to another, with an average of $2.5 \mathrm{U} \mathrm{mg}^{-1}$ at $37^{\circ} \mathrm{C}$ and $55.8 \mathrm{U} \mathrm{mg}^{-1}$ at $90^{\circ} \mathrm{C}$. Since the enzymic test of activity used in most of this study is based on the disappearance of the positive charge of the amino group of aspartate, it was verified that the presence 

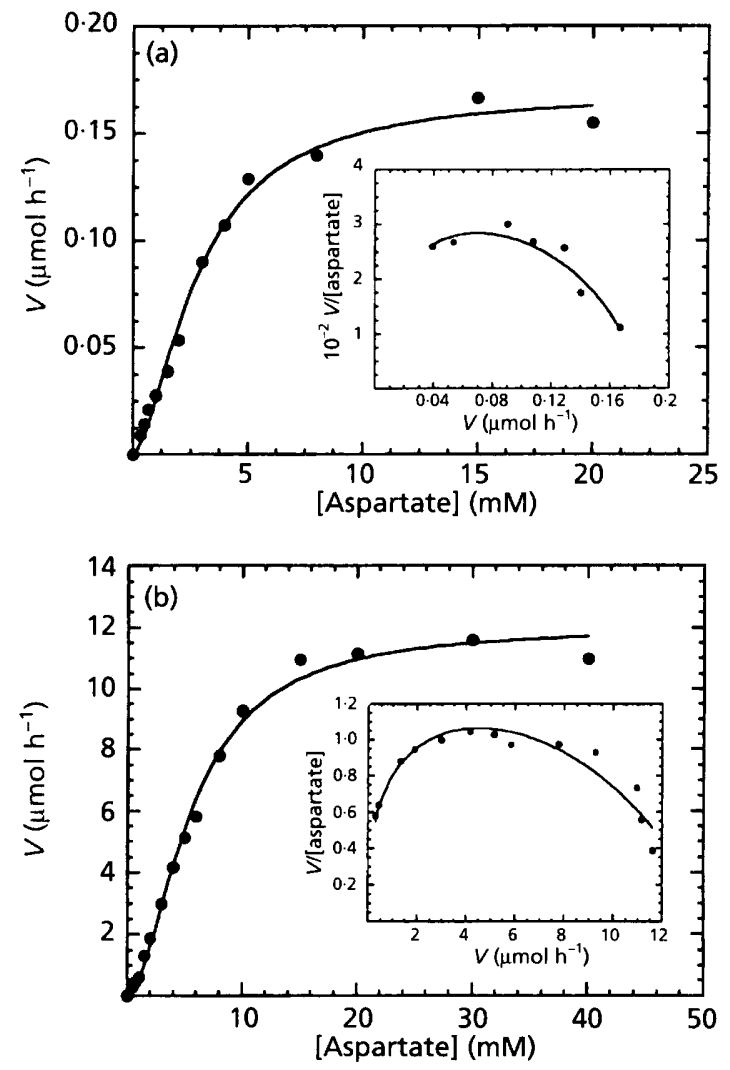

Fig. 1. Aspartate saturation curve of $P$. abyssi ATCase. ATCase activity was measured as described in Methods in the presence of increasing concentrations of aspartate. (a) Activity at $37{ }^{\circ} \mathrm{C}$ using $68 \mu \mathrm{g}$ protein. (b) Activity at $90^{\circ} \mathrm{C}$ using $215 \mu \mathrm{g}$ protein. The inserts show the corresponding Eadie plots.

of the other substrate, $\mathrm{CP}$, is necessary for the reaction to occur. Indeed, in the absence of CP, the measured ATCase activity was reduced by $99 \%$. Under the conditions used, the rate of reaction was constant over at least $60 \mathrm{~min}$ at $37^{\circ} \mathrm{C}$ and $5 \mathrm{~min}$ at $90^{\circ} \mathrm{C}$. This reaction rate was proportional to the amount of dialysed cell-free extract up to at least $1150 \mu \mathrm{g}$ total protein.

A 15-fold purification of ATCase from P. abyssi could be obtained by ion-exchange and exclusion chromatography. However, this procedure led to uncontrolled modifications of the molecular form of the enzyme accompanied by loss of its regulatory properties. Consequently the catalytic and regulatory properties of the enzyme were determined in the dialysed cell-free extracts, in which the enzyme shows stable properties.

\section{Catalytic properties of $\boldsymbol{P}$. abyssi ATCase}

Aspartate and CP saturation curves. In the presence of a saturating concentration of $\mathrm{CP}$, the aspartate saturation curve of $P$. abyssi A TCase was sigmoidal at both $37^{\circ} \mathrm{C}$ and $90^{\circ} \mathrm{C}$, suggesting the existence of homotropic cooperative interactions between catalytic sites (Fig. 1). The kinetic parameters resulting from the fit of a series of such
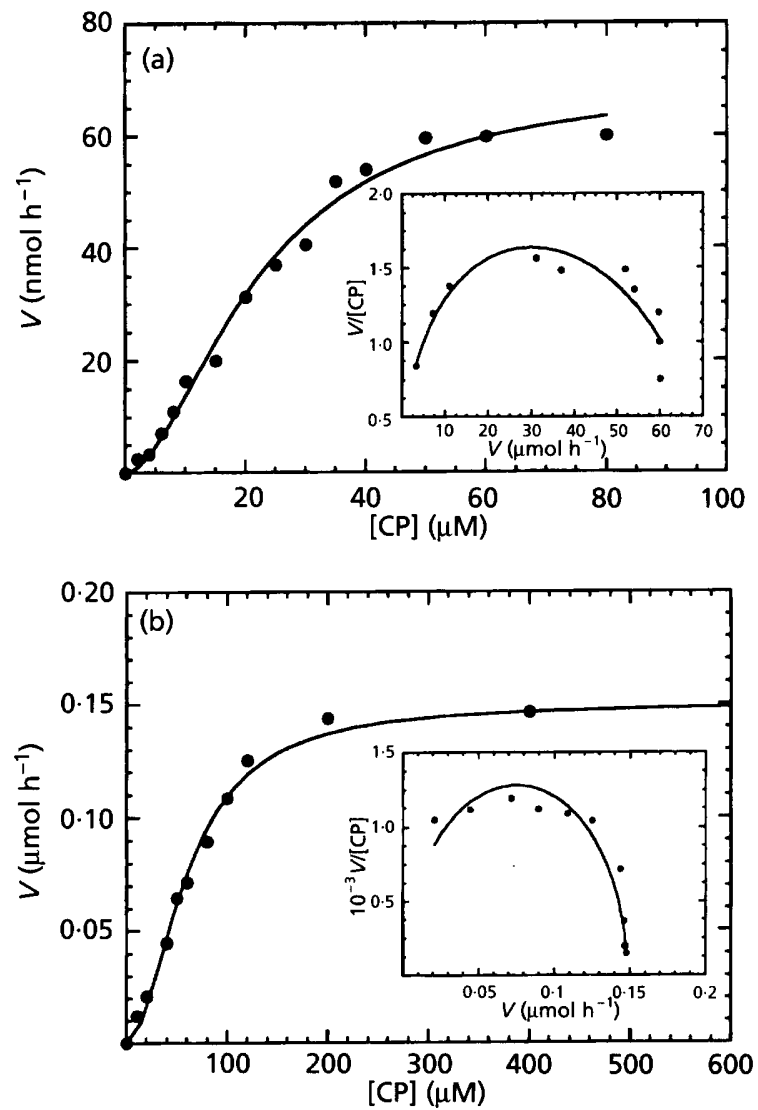

Fig. 2. $C P$ saturation curve of $P$. abyssi ATCase. ATCase activity was measured as described in Methods at $37^{\circ} \mathrm{C}$ in the presence of increasing concentrations of CP. (a) Activity in the presence of $1 \mathrm{mM}$ aspartate, using $278 \mu \mathrm{g}$ protein. (b) Activity in the presence of $20 \mathrm{mM}$ aspartate, using $106 \mu \mathrm{g}$ protein. The inserts show the corresponding Eadie plots. In (a) the standard deviation was obtained from the fit to the Hill equation; in (b) the standard deviation was calculated from three identical experimental determinations.

saturation curves to the Hill equation were $S_{0.5}=$ $3 \cdot 0 \pm 0.2 \mathrm{mM}$ aspartate and $n_{\mathrm{H}}=2 \cdot 2 \pm 0.2$ at $37^{\circ} \mathrm{C}$, values and standard deviations calculated from six determinations. At $90{ }^{\circ} \mathrm{C}$ these parameters were $S_{0.5}=5.6 \pm 0.3 \mathrm{mM}$ aspartate and $n_{\mathrm{H}}=1 \cdot 8 \pm 0 \cdot 1$.

CP saturation curves were determined at both low (1 mM) and high $(20 \mathrm{mM})$ aspartate concentrations, at $37^{\circ} \mathrm{C}$ (Fig. 2 ). This procedure was used taking into account the behaviour of E. coli ATCase. This homologous enzyme operates through an ordered mechanism in which CP binds first, followed by aspartate (Porter et al., 1969; Schaffer \& Stark, 1972; Wedler \& Gasser, 1974; Issaly et al., 1982; Hsuanyu \& Wedler, 1987; Parmentier et al., 1992). As a consequence, the CP saturation curve is sigmoidal only in the presence of a high concentration of aspartate and the apparent cooperativity for CP reflects only that for aspartate (England et al., 1994). In contrast, in the case of $P$. abyssi ATCase, the CP saturation curve is sigmoidal in the presence of both $1 \mathrm{mM}$ and $20 \mathrm{mM}$ 

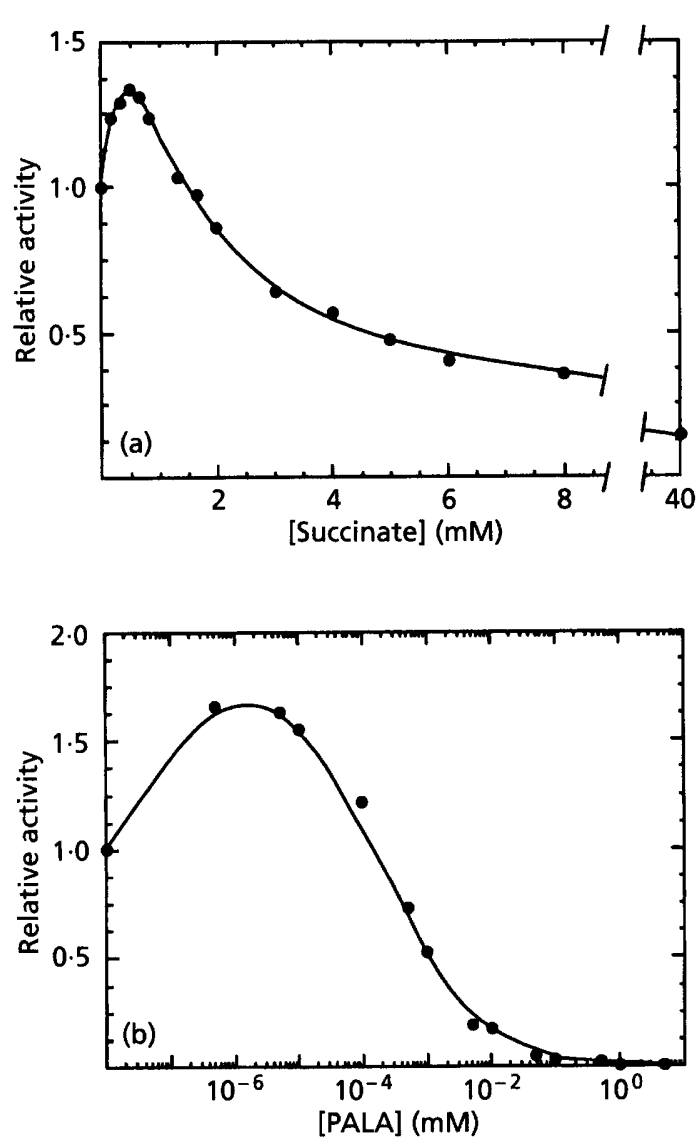

Fig. 3. Influence of succinate and PALA on the rate of reaction at low concentration of aspartate. ATCase activity was measured as described in Methods but in the presence of $2 \mathrm{mM}$ aspartate. (a) Activity at increasing concentrations of succinate. (b) Activity at increasing concentrations of PALA.

aspartate, the Hill numbers obtained being $1 \cdot 9 \pm 0 \cdot 2$ and $1 \cdot 8 \pm 0.2$ respectively. The fit of the saturation curves to the Hill equation gives an $S_{0.5}$ value of $23.4 \pm 3.2 \mu \mathrm{M}$ CP in the presence of $1 \mathrm{mM}$ aspartate and $60.0 \pm 2.3 \mu \mathrm{M} \mathrm{CP}$ in the presence of $20 \mathrm{mM}$ aspartate, values and standard deviations calculated from three determinations. In the case of both substrates, the sigmoidicity of the saturation curves is confirmed by the curvature of Eadie plots (inserts of Figs 1 and 2).

Influence of substrate analogues. It is a general property of enzymes showing cooperativity between catalytic sites that some substrate analogues, which are efficient competitive inhibitors, are able to promote the quaternary structure transition which accounts for these interactions. Such is the case of E. coli ATCase. The consequence of this phenomenon is that in the presence of a low concentration of aspartate, succinate and other analogues of this substrate increase the rate of the reaction through promoting the transition to the high affinity $\mathrm{R}$ state (Collins \& Stark, 1971; Jacobson \& Stark, 1973). This kind of experiment was performed in the case of $P$. abyss $i$ ATCase using analogues of the two substrates. Figure 3(a) shows that in the presence of $2 \mathrm{mM}$ aspartate low concentrations of succinate increased the rate of the enzyme reaction by $35 \%$. As expected, higher concentrations of succinate provoked competitive inhibition. This behaviour is identical to that of E. coli ATCase, further substantiating the conclusion that $P$. abyssi ATCase shows homotropic cooperative interactions between catalytic sites for the utilization of aspartate.

Since $P$. abyssi ATCase apparently exhibits cooperative interactions for the utilization of $\mathrm{CP}$, the same kind of experiments were performed using analogues of this substrate, which have been shown to be competitive inhibitors of E. coli and Saccharomyces cerevisiae ATCases (Porter et al., 1969; Penverne \& Hervé, 1983). Surprisingly, neither phosphonacetate nor pyrophosphate or phosphate had any influence on the reaction catalysed by $P$. abyssi ATCase, even at a concentration of $10 \mathrm{mM}$ in the presence of $30 \mu \mathrm{M} \mathrm{CP}$. This result was unexpected, since the $K_{\mathrm{i}}$ of these two compounds for the E. coli enzyme are $0.32 \mathrm{mM}$ and $0.09 \mathrm{mM}$ respectively. This lack of inhibition might be related to some particular feature of carbamoylphosphate binding to the catalytic site of $P$. abyssi ATCase. This possibility will be discussed later.

In addition, the bisubstrate analogue PALA, a strong inhibitor of ATCase from different sources (Collins \& Stark, 1971; Swyryd et al., 1974; Penverne \& Hervé, 1983), also inhibited P. abyssi ATCase. At a concentration of $11 \mu \mathrm{M}$, PALA provoked $50 \%$ inhibition of this enzyme in the presence of $5 \mathrm{mM} \mathrm{CP}$ and $20 \mathrm{mM}$ aspartate, with a $K_{\mathrm{i}}$ of $1 \cdot 1 \mu \mathrm{M}$. As in the case of succinate, low concentrations of PALA were able to increase the reaction rate catalysed by the enzyme in the presence of $2 \mathrm{mM}$ aspartate (Fig. 3b). However, the range of PALA concentrations for which such an effect was observed was much wider than in the case of succinate (Fig. 3a), in contrast with what is observed for E. coli ATCase (Collins \& Stark, 1971; Thiry \& Hervé, 1978). The significance of this unexpected observation will be discussed later. The presence of $11 \mu \mathrm{M}$ PALA abolished the apparent cooperativity for aspartate, the calculated Hill number decreasing from $1 \cdot 9 \pm 0.3$ to $1 \cdot 1 \pm 0 \cdot 2$. This observation is consistent with the results obtained in the presence of succinate, since PALA is also known to promote the $\mathrm{T}$ to $\mathrm{R}$ transition in E. coli ATCase (Collins \& Stark, 1971; Moody et al., 1979).

pH-dependence. The influence of $\mathrm{pH}$ on the rate of the reaction catalysed by $P$. abyssi ATCase was investigated. Fig. 4 shows that this rate increased uniformly up to around $\mathrm{pH}$ 9. Thus it appears that the maximal activity of this enzyme requires a higher $\mathrm{pH}$ than that of the homologous ATCase from E. coli (Gerhart \& Pardee, 1964) and S. cerevisiae (Belkaid et al., 1987).

\section{Influence of nucleotides and allosteric regulation}

Regulatory properties of $P$. abyssi ATCase were investigated and the results show that the activity of this enzyme is regulated by allosteric effectors differently at low and high temperatures. At $37^{\circ} \mathrm{C}$ it is feed-back inhibited by the two end-products CTP and UTP (Fig. 5a). Contrary 


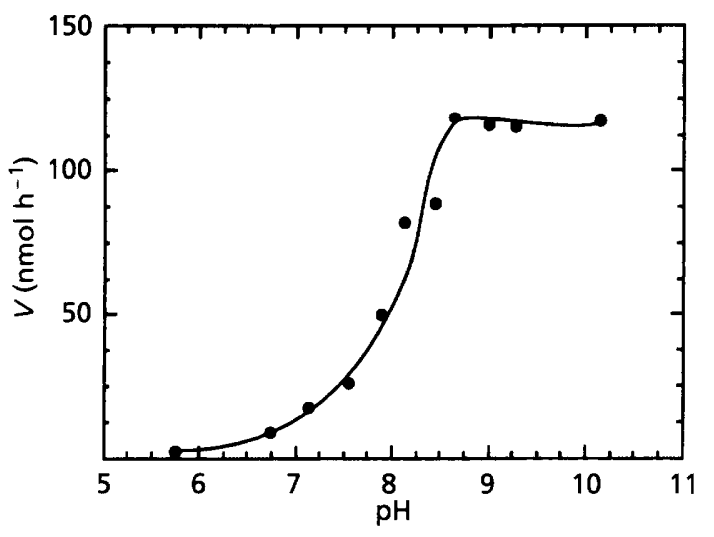

Fig. 4. $\mathrm{pH}$-dependence of $P$. abyssi ATCase. ATCase activity was measured at $37{ }^{\circ} \mathrm{C}$ as a function of $\mathrm{pH}$ as described in Methods in the presence of $5 \mathrm{mM}$ aspartate using $30 \mu \mathrm{g}$ protein.
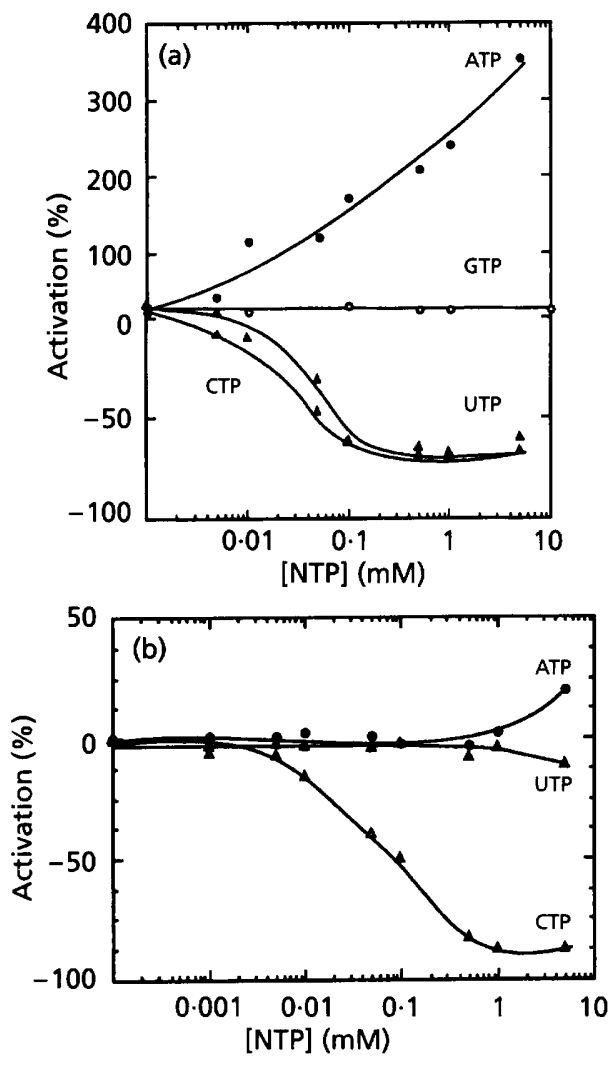

Fig. 5. Influence of allosteric effectors on the activity of $P$. abyssi ATCase. ATCase activity was measured in the presence of $3 \mathrm{mM}$ aspartate and increasing concentrations of various nucleotides. (a) Activity at $37^{\circ} \mathrm{C}$. (b) Activity at $90^{\circ} \mathrm{C}$. The percentage inhibition or activation was calculated as described in Methods.

to what is observed in the case of E. coli ATCase (Wild et al., 1989), these two effectors do not act in synergy. The influence of increasing concentrations of UTP in the

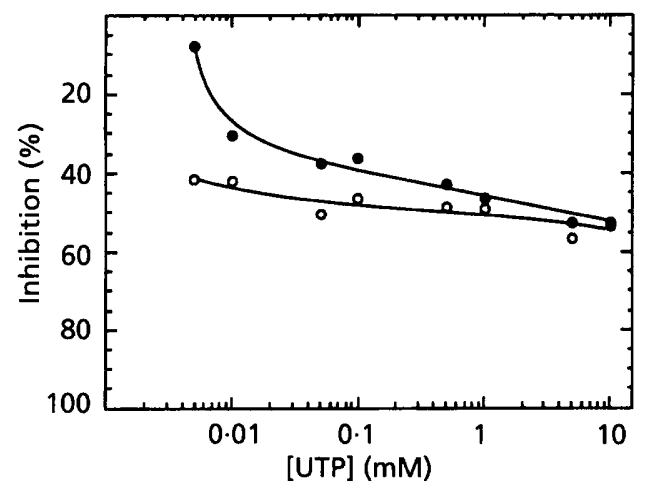

Fig. 6. Combined effects of the two feed-back inhibitors CTP and UTP. ATCase activity was measured as described for Fig. 5 using increasing concentrations of UTP and in the presence $(O)$ or absence (O) of $1 \mathrm{mMCTP}$. The percentage inhibition was calculated as described in Methods.

presence of $1 \mathrm{mM} \mathrm{CTP} \mathrm{(Fig.} \mathrm{6)} \mathrm{suggests} \mathrm{that} \mathrm{the} \mathrm{two}$ nucleotides affect the rate of the reaction equally. Their effects are simply additive until the apparent saturation of the regulatory sites. A maximal inhibition of $60 \%$ was observed, indicating that these two effectors are not competing with $\mathrm{CP}$ at the catalytic site. As in the case of E. coli ATCase, ATP is an activator and GTP has no influence on the $P$. abyssi enzyme (Fig. 5a).

Unexpectedly, at $90^{\circ} \mathrm{C}$ the activity of this enzyme is regulated only by CTP (Fig. $5 \mathrm{~b}$ ). This feed-back inhibition by CTP was not affected by the presence of $1 \mathrm{mM}$ ATP. It was verified that the lack of influence of UTP and ATP at high temperature was not due to hydrolysis of these two nucleotides or to competition with phosphate which might accumulate as a degradation product of $\mathrm{CP}$.

\section{Influence of temperature}

The influence of temperature on the catalytic properties of $P$. abyssi ATCase is of particular interest since the GE5 strain is classified as a hyperthermophilic archaeobacterium (Erauso et al., 1993). In addition, CP, one of the substrates of ATCase, is an unstable chemical (Allen \& Jones, 1964) with a half-life of only few seconds at $95^{\circ} \mathrm{C}$. Consequently, temperature effects on the activity of $P$. abyssi A TCase were investigated in different ways.

Thermostability of $P$. abyssi ATCase in absence of substrate. $P$. abyssi ATCase samples were preincubated for $15 \mathrm{~min}$ at temperatures from $37^{\circ} \mathrm{C}$ to $90{ }^{\circ} \mathrm{C}$ and the activity was then determined at $37^{\circ} \mathrm{C}$ under standard conditions. No inactivation was observed even at the highest temperature. A slight increase in activity was even observed between 37 and $65^{\circ} \mathrm{C}$. On the basis of this result, the stability of the enzyme was examined at $90{ }^{\circ} \mathrm{C}$ over a longer period. A sample of $P$. abyssi ATCase was incubated at $90^{\circ} \mathrm{C}$; aliquots were taken at different time intervals and their activity was measured at $37^{\circ} \mathrm{C}$. Under these conditions there was no loss of activity over a period 
of $6 \mathrm{~h}$. Taken together, these results show that ATCase from GE5 strain of $P$. abyss $i$ is extremely thermostable, a property that is in accordance with the natural habitat of this micro-organism.

Degradation of CP during the ATCase assay at high temperature. Temperatures higher than $37^{\circ} \mathrm{C}$ progressively degrade $\mathrm{CP}$. Therefore, the standard concentration of this substrate $(5 \mathrm{mM})$ might not be saturating the $P$. abyssi enzyme at these higher temperatures, so the kinetic analysis might be inaccurate. Knowing that E. coli and $P$. abyssi A TCase have a similar $S_{0.5}$ for $\mathrm{CP}(60 \mu \mathrm{M})$, the effect of temperature on this substrate was determined by measuring the E. coli ATCase activity at $37^{\circ} \mathrm{C}$ after 10 min preincubation of the reaction mixture containing $20 \mathrm{mM} \mathrm{CP}$ at various temperatures up to $80^{\circ} \mathrm{C}$. In these conditions, the measured reaction rate was constant up to a temperature of $55^{\circ} \mathrm{C}$, showing that this assay can be performed up to that temperature without being hindered by the heat degradation of $\mathrm{CP}$. Consequently, when the experiments were performed at $90^{\circ} \mathrm{C}$, the concentration of $\mathrm{CP}$ was $40 \mathrm{mM}$. Under these conditions the rate of the reaction was constant during $5 \mathrm{~min}$.

Influence of temperature on the reaction rate. The results reported above establish the conditions under which the influence of temperature on the $P$. abyssi ATCase reaction rate can be monitored. In order to determine the influence of temperature on the maximal velocity of this reaction, the aspartate saturation curve of the enzyme was established at different temperatures under the standard conditions described in Methods. As shown in Fig. 7, the rate of the reaction strongly increased, especially above $40^{\circ} \mathrm{C}$, and reached a maximum at $70{ }^{\circ} \mathrm{C}$. Over $70^{\circ} \mathrm{C}$ a slight decrease of activity was observed which might be due to chemical carbamylation of ATCase by cyanate, a degradation product of $\mathrm{CP}$. Indeed, preincubation at $90^{\circ} \mathrm{C}$ of the enzyme preparation for $5 \mathrm{~min}$ provoked such an inactivation, even in the presence of $20 \mathrm{mM}$ glycine as a scavenger. The Arrhenius plot (Fig. 7 insert) is biphasic, indicating an apparent activation energy $\left(E_{\mathrm{a}}\right)$ of $65.6 \mathrm{~kJ} \mathrm{~mol}^{-1}$ over the range $20-50{ }^{\circ} \mathrm{C}$, shifting to $40.9 \mathrm{k} \mathrm{J} \mathrm{mol}^{-1}$ over the range $50-70{ }^{\circ} \mathrm{C}$. From the plot of $\ln (k / T)$ as a function of $1 / T$ one can calculate an activation enthalpy $\Delta H^{\neq}$of $63.0 \mathrm{~kJ} \mathrm{~mol}^{-1}$ at $37^{\circ} \mathrm{C}$ and $\Delta H^{*}$ of $38.2 \mathrm{~kJ} \mathrm{~mol}^{-1}$ at $96^{\circ} \mathrm{C}$ and an activation entropy $\Delta S^{\neq}$of $-99.5 \mathrm{~kJ} \mathrm{~mol}^{-1} \mathrm{~K}^{-1}$ at $37^{\circ} \mathrm{C}$ and $-23 \cdot 4 \mathrm{~kJ} \mathrm{~mol}^{-1} \mathrm{~K}^{-1}$ at $96^{\circ} \mathrm{C}$.

\section{Influence of pressure}

The GE5 strain of $P$. abyssi ATCase was collected from an active chimney at a depth of $2000 \mathrm{~m}$ in the Pacific Ocean (Erauso et al., 1993), where the hydrostatic pressure is $20 \mathrm{MPa}$. In order to determine the influence that pressure could have on the activity of ATCase from this microorganism, enzyme kinetic experiments under high pressure were performed using the previously described apparatus (Hui Bon Hoa et al., 1990).

In the first kind of experiment, the influence of pressure on the enzyme stability was investigated. Samples were

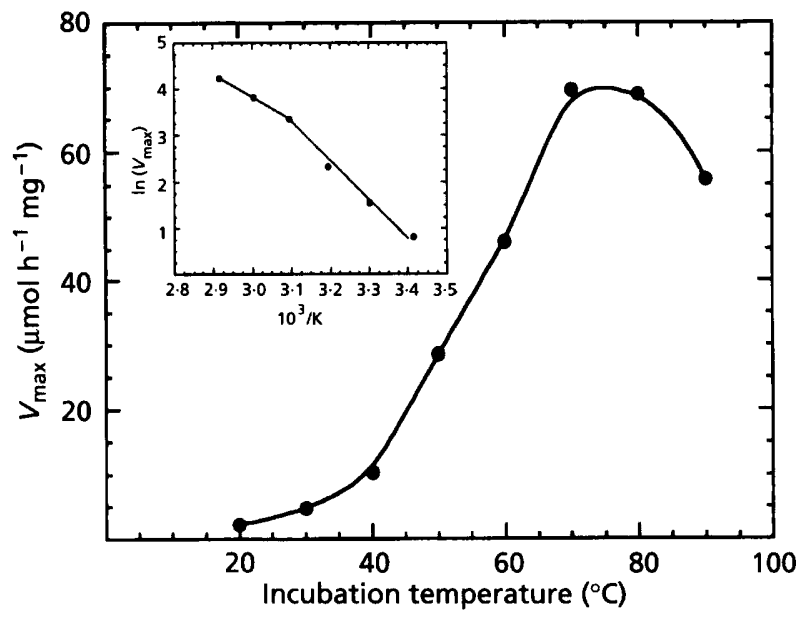

Fig. 7. Influence of temperature on the rate of the reaction catalysed by $P$. abyssi ATCase. Aspartate saturation curves of $P$. abyssi ATCase were determined at different temperatures under standard conditions as described in Methods and the maximal velocities were calculated. The insert shows the corresponding Arrhenius plot.

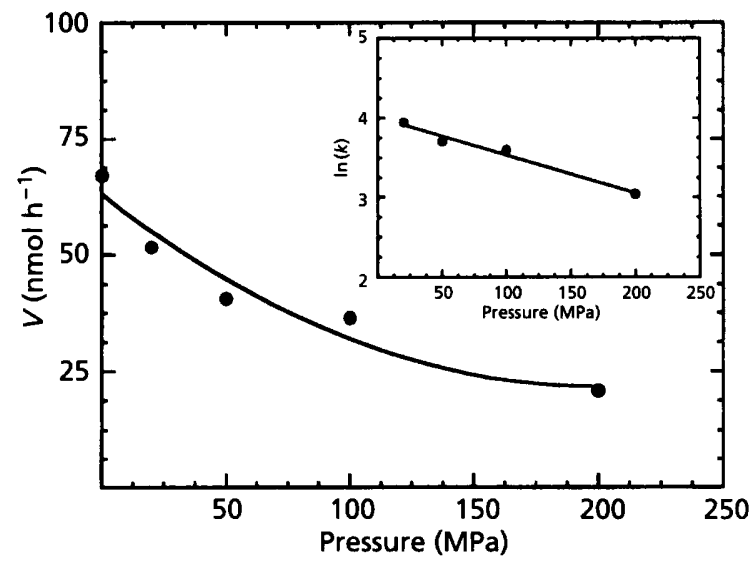

Fig. 8. Influence of pressure on the rate of the reaction catalysed by $P$. abyssi ATCase. The rate of reaction was measured as a function of pressure, as described in Methods. Each sample collected contained $108 \mu \mathrm{g}$ protein. The insert shows the apparent rate constant of the enzymic reaction as a function of pressure.

preincubated for $15 \mathrm{~min}$ under various pressures up to $200 \mathrm{MPa}$. The initial reaction rate catalysed by these samples when they are brought back to the atmospheric pressure was measured. Up to $200 \mathrm{MPa}$ pressure had no irreversible influence on the catalytic activity of $P$. abyssi ATCase. A slight activation was even observed.

In the second kind of experiment, the influence of pressure on the rate of the reaction catalysed by $P$. abyssi ATCase was directly investigated as described in Methods. As can be seen in Fig. 8, pressure had a negative effect on the reaction rate, with a $50 \%$ decrease observed at $80 \mathrm{MPa}$. 
The plot of $\ln (k)$ against pressure (Fig. 8 , insert) indicates an activation volume $\left(\Delta V^{\ddagger}\right)$ of $12 \pm 0.1 \mathrm{ml} \mathrm{mol}^{-1}$ for this enzymic reaction.

\section{DISCUSSION}

Strain GE5 of $P$. abyssi has an aspartate transcarbamoylase (ATCase), the first enzyme of the pyrimidine nucleotide pathway. Partial purification of the enzyme shows variations in its apparent molecular mass, suggesting that this enzyme is oligomeric, as in other organisms. This apparent dissociation is accompanied by an alteration of the regulatory properties of the enzyme.

P. abyssi ATCase shows homotropic cooperative interactions between the catalytic sites for the utilization of the two substrates, CP and aspartate. In the case of E. coli ATCase, the cooperativity for aspartate is well documented (Allewell, 1989; Hervé, 1989; Kantrowitz \& Lipscomb, 1990; Lipscomb, 1992). This enzyme shows apparent cooperativity for $\mathrm{CP}$ only in the presence of a high concentration of aspartate. Taking into account the fact that the reaction catalysed by $E$. coli ATCase proceeds through an ordered mechanism in which CP binds first, followed by aspartate (Porter et al., 1969; Hsuanyu \& Wedler, 1987; Parmentier et al., 1992), it was shown that this apparent cooperativity for $\mathrm{CP}$ only reflects the cooperativity for the second substrate, aspartate. At low $\mathrm{CP}$ concentration the binding of aspartate is restricted and cannot promote the transition to the $\mathrm{R}$ form, which has a high affinity for this substrate (England et al., 1994). Such is not the case in $P$. abyssi ATCase since cooperativity is observed at both low and high concentrations of aspartate, presumably when the enzyme is in the two extreme conformations involved in the homotropic cooperative interactions between the catalytic sites for the binding of this substrate.

In the case of aspartate, the existence of cooperative effects is confirmed by the influence of the substrate analogue succinate on the rate of the reaction measured in the presence of a low concentration of aspartate. As in the case of E. coli ATCase, the observed increase of the reaction rate is interpreted as resulting from the substrateanalogue-promoted transition of the enzyme from the low-affinity conformation ( $\mathrm{T}$ state) to the high-affinity conformation ( $\mathrm{R}$ state). The $S_{0.5}$ value varies from $3 \cdot 0 \pm 0 \cdot 2 \mathrm{mM}$ aspartate to $5 \cdot 6 \pm 0.3 \mathrm{mM}$ aspartate when the temperature of incubation is raised from $37^{\circ} \mathrm{C}$ to $90^{\circ} \mathrm{C}$. Such an effect is expected since the interactions between aspartate and the catalytic site of the enzyme are of an ionic nature (Krause et al., 1987).

Surprisingly, some CP analogues such as pyrophosphate and phosphonacetate, which are good competitive inhibitors of ATCase from other organisms, do not influence the reaction catalysed by $P$. abyssi ATCase. Furthermore, the bisubstrate analogue PALA does not behave similarly towards the E. coli and $P$. abyssi enzymes. In the presence of low concentrations of aspartate, maximal stimulation occurs over a much wider PALA concentration range in the case of $P$. abyssi enzyme. Taken together these results suggest the existence of some differences in the CP binding site between the two enzymes, although they bind this substrate with similar affinities. $\mathrm{CP}$ is a very unstable intermediary metabolite whose half-life at $95{ }^{\circ} \mathrm{C}$ is only a few seconds. The particular behaviour of the CP binding site of $P$. abyssi enzyme might be related to some adaptive process of channelling of this metabolite from the catalytic site of $\mathrm{CP}$ synthetase, where it is synthesized, to the catalytic site of ATCase, where it is used as substrate. Preliminary results obtained in this laboratory suggest that such a process is operating in $P$. abyssi.

The activity of $P$. abyssi ATCase is subject to allosteric regulation, although the nature of this process is temperature dependent. At $37^{\circ} \mathrm{C}$, as in E. coli ATCase, ATP acts as an activator and CTP and UTP act as feed-back inhibitors. However, in this archaeobacterium these last two effectors do not act in synergy as they do in the case of the E. coli enzyme (Wild et al., 1989; England \& Hervé, 1992). The results reported here suggest that the regulatory sites of $P$. abyssi ATCase do not differentiate between the two nucleotides and that the saturation of these sites by one or by the combination of the two effectors leads to a maximal $60 \%$ inhibition. Surprisingly, at $90{ }^{\circ} \mathrm{C}$ the activity of $P$. abyssi ATCase is sensitive only to the feed-back inhibitor CTP. Not only is ATP not an activator but it does not alter the response of the enzyme to CTP. This observation suggests that, at high temperature, either ATP does not bind to the enzyme or its regulatory signal is not transmitted.

Although ATCases are generally stable enzymes, that of $P$. abyssi is more resistant to high temperature than the $E$. coli enzyme. Upon incubation at $60^{\circ} \mathrm{C}$ for $6 \mathrm{~h}, E$. coli ATCase loses $25 \%$ of its activity (Kerbiriou \& Hervé, 1972). In contrast, the incubation of $P$. abyssi ATCase for the same period of time at $90{ }^{\circ} \mathrm{C}$ does not provoke any decrease of its activity. The determination of the primary structure of this enzyme will provide some information about the amino acid substitutions responsible for this increased thermostability. Temperature increases the maximal rate of the reaction catalysed by the $P$. abyssi enzyme up to $70^{\circ} \mathrm{C}$. The decrease observed above $80^{\circ} \mathrm{C}$ is not due to inactivation because, as we have shown, the enzyme is stable at $90^{\circ} \mathrm{C}$. The same phenomenon has been reported in the case of other enzymes from thermophilic and hyperthermophilic archaeobacteria (Breitung et al., 1992; Colombo et al., 1992; Richter \& Schafer, 1992; Wakagi et al., 1992). The biphasic nature of the Arrhenius plot suggests that at about $50^{\circ} \mathrm{C}$ the enzyme undergoes a structural transition towards a more efficient conformation which catalyses the reaction with a lower energy of activation. A similar behaviour has been observed in the case of D-glyceraldehyde-3-phosphate dehydrogenase from a thermophilic archaeobacterium (Fabry \& Hensel, 1987). Interestingly, such a break in the Arrhenius plot has also been reported in the case of $E$. coli ATCase (Wedler \& Gasser, 1974), but at a lower temperature. The substantial decrease of the enthalpy of activation and of the negative value of entropy of activation when the temperature is raised from $37{ }^{\circ} \mathrm{C}$ to $96^{\circ} \mathrm{C}$ indicates that 
the transition state of the reaction is reached more easily at high temperature.

The GE5 strain of $P$. abbysi was collected in a deep-sea hydrothermal vent located $2000 \mathrm{~m}$ deep in the ocean (Erauso et al., 1992), corresponding to a hydrostatic pressure of $20 \mathrm{MPa}$. Its growth rate is higher under this pressure (Erauso et al., 1993). The results reported here show that at $20 \mathrm{MPa}$ the rate of the reaction catalysed by $P$. abyssi ATCase is decreased by about $20 \%$, an effect which is fully reversible.

In order to understand the structural features on which the particular properties of ATCase from this hyperthermophilic archaeobacterium are based, the cloning; of the gene coding for this enzyme is being undertaken.

\section{ACKNOWLEDGEMENTS}

This work was supported by the Centre National de la Recherche Scientifique (Group de Recherche 'Bactocean') and by a fellowship from the Ministère des Affaires Étrangères to C. Purcarea. The authors are indebted to Dr George Barbier and Dr Gérard Raguenes for stimulating discussions and to Dr John Vickrey for reading and improving this manuscript.

\section{REFERENCES}

Adams, M. W. W. (1993). Enzymes and proteins from organisms that grow near and above $100^{\circ} \mathrm{C}$. Annu Rev Microbiol 47, 627-658.

Allen, C. M. J. \& Jones, M. E. (1964). Decomposition of carbamylphosphate in aqueous solutions. Biochemistry 3, 1238-1247.

Allewell, N. M. (1989). Escherichia coli aspartate transcarbamoylase: structure, energetics, and catalytic and regulatory mechanisms. Annu Rev Biophys Biochem Chem 18, 71-92.

Argos, P., Rossmann, M. G., Grau, U. M., Zuber, H., Frank, G. \& Tratschin, J. D. (1979). Thermal stability and protein structure. Biochemistry 18, 5698-5703.

Auzende, J. M., Urabe, T. \& Équipage Scientifique (1989). Le cadre géologique d'un site hydrothermal actif: la campagne 'Starmer 1' du submersible Nautile dans le bassin Nord Fidjien. C R Acad Sci Ser III Sci Vie 302, 1787-1795.

Belkaid, M., Penverne, B., Denis, M. \& Hervé, G. (1987). In :itu behavior of the pyrimidine pathway enzymes in Saccharomyces cerevisiae. 2. Reaction mechanism of aspartate transcarbamylase dissociated from carbamylphosphate synthetase by genetic alteration. Arch Biochem Biophys 254, 568-578.

Breitung, J., Borner, G., Scholz, S., Linder, D., Stetter, K. O. \& Thauer, R. K. (1992). Salt dependence, kinetic properties and catalytic mechanism of $\mathrm{N}$-formylmethanofuran: tetrahydrometanopterin formyl transferase from the extreme thermophile Methanopyrus kandleri. Eur J Biochem 210, 971-981.

Brock, T. D. (1978). Thermophilic Microorganisms and Life at High Temperatures. Edited by M. P. Starr. New York: Springer-Verlag.

Collins, K. D. \& Stark, G. R. (1971). Aspartate Transcarbamylase. Interaction with the transition state analogue $N$-(phosphonacetyl)L-aspartate. $J$ Biol Chem 246, 6599-6605.

Colombo, S., D'Auria, S., Fusi, P., Zecca, L., Raia, C. A. \& Tortora, P. (1992). Purification and characterization of a thermostable carboxypeptidase from the extreme thermophilic archaebacterium Sulfolobus solfataricus. Eur J Biocbem 206, 349-357.

Corliss, J. B. \& Ballard, R. D. (1977). Oases of life in the cold abyss. Natl Geogr Mag 152, 441-453.
Davidson, J. N., Chen, K. C., Jamison, R. S., Musmanno, L. A. \& Kern, C. B. (1993). The evolutionary history of the first three enzymes in pyrimidine biosynthesis. Bioessays 15, 157-164.

England, P. \& Hervé, G. (1992). Synergistic inhibition of Escherichia coli aspartate transcarbamylase by CTP and UTP: binding studies using continuous-flow dialysis. Biochemistry 31, 9725-9732.

England, P., Leconte, C., Tauc, P. \& Hervé, G. (1994). Apparent cooperativity for carbamylphosphate in Escherichia coli aspartate transcarbamylase only reflects cooperativity for aspartate. Eur J Biochem (in press).

Erauso, G., Charbonnier, F., Barbeyron, T., Forterre, P. \& Prieur, D. (1992). Preliminary characterization of a hyperthermophilic archaebacterium with a plasmid, isolated from a North Fiji basin hydrothermal vent. C R Acad Sci Ser III Sci Vie 314, 387-393.

Erauso, G., Reysenbach, A.-L., Godfroy, A., Meunier, J.-R., Crump, B., Partensky, F., Baross, J. A., Marteinsson, V., Barbier, G., Pace, N. R. \& Prieur, D. (1993). Pyrococcus abyssi sp. nov., a new hyperthermophilic archaeon isolated from a deep sea hydrothermal vent. Arch Microbiol 160, 338-349.

Fabry, S. \& Hensel, R. (1987). Purification and characterization of $\alpha$ glyceraldehyde-3-phosphate dehydrogenase from the thermophilic archaeobacterium Methanothermus fervidus. Eur $J$ Biochem 165, 147-155.

Ganter, C. \& Plückthun, A. (1990). Glycine to alanine substitutions in helices of glyceraldehyde-3-phosphate dehydrogenase: effects on stability. Biochemistry 29, 9395-9402.

Gerhart, J. C. \& Pardee, A. B. (1964). Aspartate transcarbamylase, an enzyme designed for feed-back inhibition. Fed Proc 23, 727-735.

Hervé, G. (1989). Aspartate transcarbamylase from Escherichia coli. In Allosteric Enzymes, pp. 62-79. Edited by G. Hervé. Boca Raton, Florida: CRC.

Hervé, G., Nagy, M., Le Gouar, M., Penverne, B. \& Ladjimi, M. (1993). The carbamoyl phosphate synthetase-aspartate transcarbamoylase complex of Saccharomyces cerevisiae; molecular and cellular aspects. Biochem Soc Trans 21, 195-198.

Hsuanyu, Y. \& Wedler, F. C. (1987). Kinetic mechanism of native Escherichia coli aspartate transcarbamylase. Arch Biochem Biophys 259 , 316-330.

Hui Bon Hoa, G., Hamel, G., Else, A., Weill, G. \& Hervé, G. (1990). A reactor permitting injection and sampling for steady state studies of enzymatic reactions at high pressure: tests with aspartate transcarbamylase. Anal Biochem 187, 258-261.

Imanaka, T., Shibazaki, M. \& Takagi, M. (1986). A new way of enhancing the thermostability of proteases. Nature 324, 695-697.

Ishikawa, K., Nakamura, H., Morikawa, K., Kimura, S. \& Kanaya, S. (1993). Cooperative stabilization of Escherichia coli ribonuclease $\mathrm{HI}$ by insertion of Gly-80b and Gly-77 $\rightarrow$ Ala substitution. Biochemistry 32, 7136-7142.

Issaly, I., Poiret, M., Tauc, P., Thiry, L. \& Hervé, G. (1982). Interactions of Cibacton blue F3GA and nucleotides with Escherichia coli aspartate carbamoyltransferase and its subunits. Biochemistry 21, 1612-1623.

Jacobson, G. R. \& Stark, G. R. (1973). Aspartate transcarbamylases. In The Enzymes, pp. 225-308. Edited by P. D. Boyer. New York: Academic Press.

Kantrowitz, E. R. \& Lipscomb, W. N. (1990). Escherichia coli aspartate transcarbamylase: The molecular basis for a concerted allosteric transition. Trends Biocbem Sci 15, 53-59.

Kerbiriou, D. \& Hervé, G. (1972). An Aspartate transcarbamylase lacking catalytic subunit interactions. I. Disconnection of homotropic and heterotropic interactions under the influence of 2thiouracil. J Mol Biol 64, 379-392. 
Krause, K. L., Volz, K. W. \& Lipscomb, W. N. (1987). The $2.5 \AA$ structure of aspartate carbamoyltransferase complexed with the bisubstrate analogue $N$-(phosphonacetyl)-L-aspartate. $J$ Mol Biol 193, 527-553.

Leger, D. \& Hervé, G. (1988). Allostery and $\mathrm{p} K_{\mathrm{a}}$ changes in aspartate transcarbamoylase from Escherichia coli: analysis of the $\mathrm{pH}$ dependence in the catalytic subunits. Biochemistry 27, 4293-4298.

Lipscomb, W. N. (1992). Activity and regulation in aspartate transcarbamylase. Regulation of Proteins by Ligands. Edited by R. J. V. Johnson. Houston: The Robert A. Welch Foundation Conference on Chemical Research.

Lowe, S. E., Jain, M. K. \& Zeikus, J. G. (1993). Biology, ecology, and biotechnological applications of anaerobic bacteria adapted to environmental stresses in temperature, $\mathrm{pH}$, salinity, or substrates. Microbiol Rev 57, 451-509.

Moody, M. F., Vachette, P. \& Foote, A. M. (1979). Changes in the $\mathrm{X}$-ray solution scattering of aspartate transcarbamylase following the allosteric transition. J Mol Biol 133, 517-532.

Parmentier, L. E., Oleary, M. H., Schachman, H. K. \& Cleland, W. W. (1992). ${ }^{13} \mathrm{C}$ isotope effects as a probe of the kinetic mechanism and allosteric properties of Escherichia coli aspartate transcarbamylase. Biochemistry 31, 6570-6576.

Penverne, B. \& Hervé, G. (1983). In situ behavior of the pyrimidine pathway enzymes in Saccharomyces cerevisiae. I. Catalytic and regulatory properties of aspartate transcarbamylase. Arch Biochem Biopbys 225, 562-575.

Perbal, B. \& Hervé, G. (1972). Biosynthesis of Escherichia coli aspartate transcarbamylase. I. Parameters of gene expression and sequential biosynthesis of the subunits. J Mol Biol 70, 511-529.

Porter, R. W., Modebe, M. O. \& Stark, G. R. (1969). Aspartate transcarbamylase. Kinetic studies of the catalytic subunit. $J$ Biol Chem 244, 1846-1859.

Prescott, L. M. \& Jones, M. E. (1969). Modified methods for the determination of carbamyl aspartate. Anal Biochem 32, 408-419.

Richter, O.-M. H. \& Schafer, G. (1992). Purification and enzymic characterization of the cytoplasmic pyrophosphatase from the thermoacidophilic archaebacterium Thermoplasma acidophilum. Eur J Biochem 209, 343-349.

Schaffer, M. H. \& Stark, G. R. (1972). Aspartate transcarbamylase is not a ping-pong enzyme. Biochem Biophys Res Commun 46, 2082-2086.

Stetter, K. O., Fiala, G., Huber, G. \& Segerer, A. (1990). Hyperthermophilic microorganisms. FEMS Microbiol Rev 75, 117-124.

Swyryd, E. A., Seaver, S. S. \& Stark, G. R. (1974). N(phosphonacetyl)-L-aspartate, a potent transition state analog inhibitor of aspartate transcarbamylase, blocks proliferation of mammalian cells in culture. J Biol Chem 249, 6945-6950.

Thiry, L. \& Hervé, G. (1978). The stimulation of Escherichia coli aspartate transcarbamoylase activity by adenosine triphosphate. Relations with the other regulatory conformational changes; a model. J Mol Biol 125, 515-534.

Wakagi, T., Lee, C.-H. \& Oshima, T. (1992). An extremely stable inorganic pyrophosphatase purified from the cytosol of a thermoacidophilic archaebacterium, Sulfolobus acidocaldaricus strain 7 . Biochim Biophys Acta 1120, 289-296.

Wedler, F. C. \& Gasser, F. J. (1974). Modes of modifier actions in E. coli aspartate transcarbamylase. Arch Biochem Biophys 163, 69-78.

Wild, J. R., Loughrey-Chen, S. J. \& Corder, T. S. (1989). In the presence of CTP, UTP becomes an allosteric inhibitor of aspartate transcarbamoylase. Proc Natl Acad Sci US A 86, 46--50.

Woese, C. R., Kandler, O. \& Wheelis, M. L. (1990). Towards a natural system of organisms: Proposal for the domains Archae, Bacteria, and Eucarya. Proc Natl Acad Sci USA 87, 4576-4579.

Yutani, K., Ogasahara, K., Kimura, A. \& Sugino, Y. (1982). Effect of single amino acid substitutions at the same position on stability of a two-domain protein. J Mol Biol 160, 387-390.

Received 24 January 1994; revised 14 March 1994; accepted 24 March 1994. 